\title{
Integration needs in assessments of nanotechnology in food and agriculture
}

\author{
Ellen-Marie Forsberg ${ }^{1} \&$ Carolien de Lauwere $^{2}$ \\ ${ }^{1}$ Oslo and Akershus University College of Applied Sciences, ellenmarie.forsberg@hioa.no \\ ${ }^{2}$ LEI Wageningen UR, carolien.delauwere@wur.nl
}

In this article we present a study of assessments of nanotechnology in food and agriculture. The study was conducted as a part of a project studying the need for integrated assessment of emerging science and technologies. The article first introduces central hopes and concerns regarding nanotechnology in food and agriculture, and how these are assessed in different assessment spheres. The question of whether there is a need for more integration in assessments in this field is then introduced and the multiple interpretations of this notion are discussed, first in a sustainability context and then in the specific context of emerging science and technologies. This serves as the basis for analysing the current status of integration of nano-food assessments. The validity of our findings is discussed and the article ends with a summary of the main conclusions from the discussion.

Keywords: nanotechnology, sustainability, emerging technologies, integrated assessment

\section{Introduction}

Nanotechnology is the manipulation of matter on an atomic and molecular scale (1- 100 $\mathrm{m}^{-9}$ ). Such manipulation may give materials new properties; for instance, make them stronger or more reactive. Nanotechnology is in fact not one technology, but a diverse bundle of technologies operating at the nano level. In the food and agriculture sector alone there are a broad range of potential applications (see the special issue on food and agricultural applications of nanotechnology in the journal Trends in Food Science \& Technology, vol. 22, issue 11, pp. 583-640). Some examples of nanotechnology food applications are 'protection from oxidation, controlled release of encapsulated nutrients, taste masking, delivery of nanoencapsulated nutraceuticals, vitamins and flavours, detection of pathogens in food systems, food safety and quality analysis' (Sozer \& Kokini 2009: 83). Applications in packaging include 'gas and moisture barriers, tensile strength, shelf life extension via active packaging, nanoadditives, intelligent packaging, delivery and controlled release of neutraceuticals, antibacterial or self-cleaning packaging and monitoring product conditions during transportation' (Sozer \& Kokini 2009: 83). Agricultural applications include nanotechnologyenabled delivery of agriculture chemicals, field-sensing systems to monitor the environmental stresses and crop conditions, and improvement of plant traits against environmental 
stresses and diseases (Chen \& Yada 2011). Applications within animal husbandry might include improving feeding efficiency and nutrition of agricultural animals, minimizing losses from animal diseases, and turning animal by-products and waste and environmental concerns into value-added products (Chen \& Yada 2011).

As promising as it seems, the same properties that provide new possibilities for innovation also present new risks. There are worries and disagreements about the impact nanoparticles may have on human health, animals, and the environment. In addition to toxicological concerns, there are ethical concerns about human enhancement, self-replicating nanorobots, new monitoring potentials, the moral acceptability of manipulating the basics of life, and so on. The Eurobarometer 2010 study on biotechnology (Gaskell et al. 2010) shows that the European public is largely uninformed about nanotechnology, but still somewhat cautious. It has therefore been important for private and public decision makers to avoid similar controversies as was seen in Europe with regard to genetic modification (GM) technologies (especially related to food and agriculture). The result is what (Kaiser et al. 2010) call an 'assessment regime', where a host of actions have been taken to map public attitudes, engage the public in discussions, and provide evidence for policy making and regulation. Royal societies, technology boards, ethics committees, and research consortia have organised actions and events including expert committee reports and the engagement of stakeholders, lay people, and/or experts in different participatory processes. Such activities are carried out based on requests from politicians or ministries, based on the institutions' own priorities, or based on calls for proposals from the European Community (EC) framework programmes for research or national research programmes.

In addition to such events and assessment projects, nanotechnology is also subjected to the established system of risk and impact assessment. The European Community Regulation on chemicals and their safe use (REACH) incorporates nanomaterials, even if it is not specifically adapted to nanotechnology, but rather to bulk chemicals. With regard to nanotechnology applications in food, all novel foods are regulated in the Novel Foods Regulation (EC 258/97), where it is stated that they shall be properly assessed with regard to health risks. Environmental risk assessments are carried out by a number of research groups, but formalised environmental risk assessment procedures, regulations, and institutions are lacking. There is also existing regulation requiring impact assessments of larger projects and programmes in the European Commission and in national governments.

This diversity of assessment mechanisms - which again rely on a great volume of research - implies that much evidence on facts and values are produced. However, it is still up for discussion as to what extent these assessments capture scientific and societal complexity and controversy in this field, leading to robust, responsible, and sustainable technology policy and governance. The EC Code of Conduct on Responsible Nanosciences and Nanotechnologies Research stresses that nanotechnology development should contribute to sustainable development, be conducted in accordance with the precautionary principle, and be developed to the benefit of society and the environment (European Commission 2008: 6). In order to carry out this multidimensional holistic politics in practice, assessments of a quite comprehensive sort seem to be required. Under a call for projects developing an 'integrated framework for assessing emerging science and technologies', 
the European Commission states that the 'current Knowledge Assessment frameworks, that is frameworks conducive to an assessment of specific advances in science, technology and innovation, are no longer sufficient for debating and shaping the next waves of innovations and further areas where research is urgently needed' (European Commission 2010: 13). There is therefore a need for an integrated framework 'conducive to a better and more balanced assessment of emerging sciences, technologies, and related societal innovations' (European Commission 2010: 14). But what exactly is meant by integrated assessment here? And how exactly should such integrated assessments be carried out?

In this article, we will discuss findings from a European research project on integrated assessment of emerging science and technologies (EST-Frame), funded under the particular topic mentioned earlier. In particular, we will present findings from a case study of nanotechnology in food and agriculture. In this case study, 31 important Dutch and international assessments were screened, and 16 assessments were analysed in detail. The purpose was to provide an overview of the current assessment status in the field in order to identify potential needs for better integration in assessments. In addition to the document and literature review, 12 interviews were conducted with central practitioners and stakeholders involved with nanotechnology assessments in the Netherlands, and a workshop was organised in the Netherlands where results were presented and needs for integration were discussed.

In this article, we will first discuss different notions of integrated assessment. We will present central dimensions of integration for the assessment of EST, and analyse the results of the EST-Frame case study on nanotechnology in food and agriculture on these dimensions. We will start by discussing integrated assessment in the context of integrated sustainability assessments as this is where this concept has been more thoroughly developed.

\title{
Sustainability and integrated sustainability assessments
}

There is an established tradition for integrated assessments in a European policy context, related to the overarching policy goal of sustainability. The EU Sustainable Development Strategy explains that sustainable development

\begin{abstract}
is about safeguarding the earth's capacity to support life in all its diversity and is based on the principles of democracy, gender equality, solidarity, the rule of law and respect for fundamental rights, including freedom and equal opportunities for all. It aims at the continuous improvement of the quality of life and well-being on Earth for present and future generations. To that end it promotes a dynamic economy with full employment and a high level of education, health protection, social and territorial cohesion and environmental protection in a peaceful and secure world, respecting cultural diversity. (Council of the European Union 2006: 2)
\end{abstract}

As described in a United Nations report (United Nations General Assembly 2005), sustainable development is often portrayed, in a more simplistic way, as resting on three pillars, between which there needs to be a balance: economy, society, and the environment. This means that in order to determine whether any particular practice, policy, or technology is sustainable there is a need to do cross-disciplinary assessments that take into 
account all these three dimensions. There have been a host of approaches to assessing sustainability in an integrated way: some purely academic and some implemented into policy. The European Commission makes clear that its impact assessment system 'contributes to sustainable development by assessing the potential impacts of new legislation or policy proposals in economic, social and environmental fields through an integrated approach' (The European Commission 2009: 3, italics added). The approach explicitly 'replaces the previous single-sector-type assessments and assesses the potential impacts of new legislation or policy proposals in economic (including competitiveness), social, and environmental fields. It consists of a balanced appraisal of all impacts. [...] Wideranging consultation with stakeholders is an integral part of the impact assessment approach' (European Commission 2009b). In addition to its impact assessment system, the European Commission also carries out specific Strategic Environmental Assessments (SEA), as well as Trade Sustainable Impact Assessments, and so on, with the same goal of integrating the three dimensions of economy, society, and the environment. Sustainability assessments have been particularly used in the management of environmental resources, like air, water, and land, and with regard to regional development actions.

Although the notion of integrated assessment is firmly established in policy, its meaning is not singularly defined. Scrase and Sheate (2002) have identified 14 different meanings of 'integrated' related to 'integrated assessments' in environmental governance: better coordination and dissemination of data; inclusion of specific environmental values into assessments; better coordination between high-level and more local-level governance; not isolating specific environmental problems at the cost of the whole; seeing regions as units of management; life cycle analysis; integration of business concerns into governance; integration of the three pillars of sustainability into governance; integration across policy domains; integrated computer modelling; integration of other stakeholders into governance; integration among assessment tools; integration of equity concerns into governance; and proper integration of assessment into governance. All of these interpretations have relevance for the assessment of emerging food technologies, such as nanotechnologies.

\section{Interpretations of integrated assessment relevant for emerging technologies}

We have seen that the integrated sustainability assessment tradition offers important resources for discussing integrated assessment of emerging technologies, such as nanotechnology in food and agriculture. However, assessment of emerging technologies raises some particular challenges that do not seem to be adequately addressed in this tradition. We can illustrate the even broader range of interpretations of integrated assessment relevant for emerging science and technologies by Table 1 . Here we have included Scrase and Sheate's 14 meanings, slightly modified (marked by an asterix in the table). We have also included additional interpretations of integration, identified in our interviews, literature studies, and dialogues with assessment practitioners and stakeholders. 
Table 1. A matrix of interpretations of integrated assessment based on Scrase and Sheate (2002) and on interviews, literature studies, and dialogues with assessment practitioners and stakeholders

\begin{tabular}{|c|c|c|c|c|c|}
\hline & $\begin{array}{l}\text { Assessment } \\
\text { data/topics }\end{array}$ & $\begin{array}{l}\text { Assessment } \\
\text { element } \\
\text { (methods) }\end{array}$ & $\begin{array}{l}\text { Assessment } \\
\text { participants }\end{array}$ & $\begin{array}{l}\text { Assessment } \\
\text { as a whole }\end{array}$ & Governance \\
\hline $\begin{array}{l}\text { Assessment } \\
\text { data/topics }\end{array}$ & $\begin{array}{l}\text { a) Better coordi- } \\
\text { nation of data }\end{array}$ & & & & \\
\hline $\begin{array}{l}\text { Assessment } \\
\text { element } \\
\text { (methods) }\end{array}$ & $\begin{array}{l}\text { b) Life cycle ana- } \\
\text { lysis }{ }^{\star} \\
\text { c) Integrated } \\
\text { computer mo- } \\
\text { delling* }\end{array}$ & & & & \\
\hline \multicolumn{6}{|l|}{$\begin{array}{l}\text { Assessment par- } \\
\text { ticipants }\end{array}$} \\
\hline $\begin{array}{l}\text { Assessment as a } \\
\text { whole }\end{array}$ & $\begin{array}{l}\text { d) Inclusion of } \\
\text { all types of consi- } \\
\text { derations into } \\
\text { assessments } \\
\text { e) Inclusion of } \\
\text { values into } \\
\text { assessments } \\
\text { f) Inclusion of } \\
\text { narratives/visio- } \\
\text { ns/worldviews } \\
\text { into assessments } \\
\text { g) Not isolating } \\
\text { one topic at the } \\
\text { expense of the } \\
\text { whole } \\
\text { h) Explicating } \\
\text { assessment } \\
\text { framing }\end{array}$ & $\begin{array}{l}\text { i) Better integra- } \\
\text { tion among } \\
\text { assessment ele- } \\
\text { ments* } \\
\text { j) Some specific } \\
\text { elements (like } \\
\text { anticipation) are } \\
\text { necessary in } \\
\text { assessments } \\
\text { k) Targeted use } \\
\text { of methods in } \\
\text { assessment }\end{array}$ & $\begin{array}{l}\text { 1) Integration of } \\
\text { stakeholders/the } \\
\text { public into } \\
\text { assessments } \\
\text { m) Integrated } \\
\text { projects }\end{array}$ & $\begin{array}{l}\text { n) Integration } \\
\text { among assess- } \\
\text { ments }\end{array}$ & $\begin{array}{l}\text { o) Better integra- } \\
\text { tion of gover- } \\
\text { nance concerns } \\
\text { into assessments }\end{array}$ \\
\hline Governance & $\begin{array}{l}\text { p) Better disse- } \\
\text { mination of data } \\
\text { q) Balanced inte- } \\
\text { gration of con- } \\
\text { cerns into } \\
\text { governance }\end{array}$ & & $\begin{array}{l}\text { r) Integration of } \\
\text { stakeholders and } \\
\text { the public into } \\
\text { governance }^{*}\end{array}$ & $\begin{array}{l}\text { s) Better integra- } \\
\text { tion of assess- } \\
\text { ment into } \\
\text { governance }^{*}\end{array}$ & $\begin{array}{l}\text { t) Better gover- } \\
\text { nance coordina- } \\
\text { tion (between } \\
\text { sectors, levels, } \\
\text { etc.) }\end{array}$ \\
\hline
\end{tabular}

However, the rich description of interpretations of integration seemed to be unnecessarily complex for the purposes of the EST-Frame project and we chose to select a more focused list for the analytic purposes of the nano-food case study. The EST-Frame project is specifically oriented towards the organisation and design of assessments. Therefore, the most important dimensions are those related to assessment design, including participation. We therefore excluded the questions of integration that focused solely on governance issues. However, the way assessment is incorporated into governance is of importance, and is included. We have also excluded data-processing integration as such 
models of integration are on a level that is too technical for the purpose of the project. Finally, we chose to exclude integrated socio-technical research, as this is an interdisciplinary research strategy that is carried out internally in research projects and not intended as assessments targeted towards wider societal groups or policy makers. ${ }^{1}$

This leaves us with the following ways to understand integration in assessments (Table 2):

Table 2. Interpretations of integration in assessments

\begin{tabular}{|l|l|}
\hline Integration of assessment topics & $\begin{array}{l}\text { a) Inclusion of all areas of topics into assess- } \\
\text { ments } \\
\text { b) Inclusion of values into assessments } \\
\text { c) Inclusion of narratives into assessments } \\
\text { d) Not isolating one topic at the expense of the } \\
\text { whole } \\
\text { e) Explicating assessment framing }\end{array}$ \\
\hline $\begin{array}{l}\text { Integration of assessment elements/ } \\
\text { methods }\end{array}$ & $\begin{array}{l}\text { f) Some specific elements (like anticipation) are } \\
\text { necessary in assessments } \\
\text { g) Targeted use of methods in assessment }\end{array}$ \\
\hline $\begin{array}{l}\text { Integration of assessment partici- } \\
\text { pants }\end{array}$ & $\begin{array}{l}\text { h) Integration of stakeholders/the public into as- } \\
\text { sessments }\end{array}$ \\
\hline Integration between assessments & i) Integration among assessments \\
\hline $\begin{array}{l}\text { Integration of assessment and gover- } \\
\text { nance }\end{array}$ & $\begin{array}{l}\text { j) Integration of governance concerns into } \\
\text { assessments } \\
\text { k) Better integration of assessments into gover- } \\
\text { nance }\end{array}$ \\
\hline
\end{tabular}

In the EST-Frame project we could have argued for the prime importance of one selected interpretation. However, we have rather chosen to address all these different dimensions of integrated assessment and explore how they each address important methodological concerns related to responsible technology assessment and governance. We will now proceed to use the list of interpretations of integration in Table 2 and apply it on a selection of Dutch and international assessments of relevance to nanotechnology in food. This will allow us to illustrate in what respects the reviewed nanotechnology assessments are characterised by adequate integration, and where there seems to be a gap to be filled. First, we will present the study. 


\section{A study of assessments in nanotechnology in food and agriculture}

In the EST-Frame case study on nanotechnology in food and agriculture, 18 assessments (6 Dutch and 12 international) were analysed using a standardised approach developed for the EST-Frame project. This included analysing the assessments with regard to their purpose and their process characterisation. A purpose analysis table developed in the Technology Assessment in Europe; between Method and Impact (TAMI) project was applied (see Decker \& Ladikas 2004). A process characterisation table was developed within the project to give systematic information on dimensions considered important in the project. In addition, basic information about the assessments was described. The assessments were selected in a screening process on the basis of their prominence and diversity of methods (i.e. risk assessment, ethics assessment, technology assessment (TA), etc.). Pure research articles were excluded. ${ }^{2}$

The assessments that were reviewed are listed in Table 3.

Table 3. Assessments reviewed in the case study

\begin{tabular}{|c|c|c|c|c|}
\hline & Assessment name & When/Where & $\begin{array}{l}\text { Organiser/ } \\
\text { Policy domain }\end{array}$ & $\begin{array}{l}\text { Type of assessment } \\
\text { (method) }\end{array}$ \\
\hline 1 & Down on the Farm & 2004/Canada & ETC group/NGO & Technology assessment \\
\hline 2 & $\begin{array}{l}\text { Nanologue (we need to talk } \\
+ \text { background paper Annex) }\end{array}$ & 2005-2006/EU & EC (FP6)/Research & $\begin{array}{l}\text { Deliberative/Participa- } \\
\text { tory } \\
\text { Development of } \\
\text { method }\end{array}$ \\
\hline 3 & $\begin{array}{l}\text { Delphi survey and Consu- } \\
\text { mer conference on the per- } \\
\text { ception of nanotechnology }\end{array}$ & 2006/Germany & $\begin{array}{l}\text { German Federal } \\
\text { Institute for Risk } \\
\text { Assessment (BfR) }\end{array}$ & $\begin{array}{l}\text { Delphi survey/Consu- } \\
\text { mer conference }\end{array}$ \\
\hline 4 & $\begin{array}{l}\text { Nanodialogues } \\
\text { (experiments } 2 \text { and } 4 \text { ) }\end{array}$ & $\begin{array}{l}\text { 2006/United } \\
\text { Kingdom }\end{array}$ & Demos/Think Tank & $\begin{array}{l}\text { Deliberative/participa- } \\
\text { tory }\end{array}$ \\
\hline 5 & $\begin{array}{l}\text { Out of the laboratory and } \\
\text { onto our plates }\end{array}$ & $\begin{array}{l}\text { 2008/Internatio- } \\
\text { nal }\end{array}$ & $\begin{array}{l}\text { Friends of the Earth/ } \\
\text { NGO }\end{array}$ & $\begin{array}{l}\text { Technology } \\
\text { assessment }\end{array}$ \\
\hline 6 & $\begin{array}{l}\text { SCENIHR Risk assessment } \\
\text { of products of nanotechno- } \\
\text { logy }\end{array}$ & 2009/EU & $\begin{array}{l}\text { SCENIHR/EC, } \\
\text { DG SANCO }\end{array}$ & $\begin{array}{l}\text { Guidelines risk assess- } \\
\text { ment }\end{array}$ \\
\hline 7 & $\begin{array}{l}\text { Nanotechnology in the Food } \\
\text { Sector. Study. }\end{array}$ & $\begin{array}{l}\text { 2009/Switzer- } \\
\text { land }\end{array}$ & $\begin{array}{l}\text { STOA/TA Swiss/In- } \\
\text { dependent compe- } \\
\text { tence centre }\end{array}$ & $\begin{array}{l}\text { Technology } \\
\text { assessment }\end{array}$ \\
\hline 8 & $\begin{array}{l}\text { IRGC Risk Governance of } \\
\text { Nanotechnology in Food }\end{array}$ & $\begin{array}{l}2008 \text { (report) } \\
2009 \text { (policy } \\
\text { brief) Internati- } \\
\text { onal/Switzer- } \\
\text { land }\end{array}$ & $\begin{array}{l}\text { IRGC/Independent } \\
\text { foundation }\end{array}$ & $\begin{array}{l}\text { Guidelines risk gover- } \\
\text { nance }\end{array}$ \\
\hline 9 & $\begin{array}{l}\text { FAO and WHO expert me- } \\
\text { eting }\end{array}$ & $\begin{array}{l}\text { 2010/internatio- } \\
\text { nal }\end{array}$ & $\begin{array}{l}\text { FAO, WHO/Interna- } \\
\text { tional body (UN) }\end{array}$ & Expert meeting \\
\hline
\end{tabular}


Table 3. forts.

\begin{tabular}{|c|c|c|c|c|}
\hline & Assessment name & When/Where & $\begin{array}{l}\text { Organiser/ } \\
\text { Policy domain }\end{array}$ & $\begin{array}{l}\text { Type of assessment } \\
\text { (method) }\end{array}$ \\
\hline 10 & $\begin{array}{l}\text { Framing nano (final + Delp- } \\
\text { hi report) }\end{array}$ & 2010/EU & EC (FP7)/Research & $\begin{array}{l}\text { Deliberative/Delphi } \\
\text { survey/ Development } \\
\text { of method }\end{array}$ \\
\hline 11 & $\begin{array}{l}\text { EFSA Guidelines on risk as- } \\
\text { sessment of the application } \\
\text { of nanoscience and na- } \\
\text { notechnologies in the food } \\
\text { and feed chain }\end{array}$ & 2011/EU & EFSA/EC body & $\begin{array}{l}\text { Guidelines risk assess- } \\
\text { ment }\end{array}$ \\
\hline 12 & $\begin{array}{l}\text { Health impact of nanotech- } \\
\text { nologies in food production }\end{array}$ & 2007 & RIKILT & Risk analysis \\
\hline 13 & $\begin{array}{l}\text { Workshop with Dutch Food } \\
\text { Safety Agency of nano-food } \\
\text { safety }\end{array}$ & 2007 & Rathenau/VWA & $\begin{array}{l}\text { Deliberative/participa- } \\
\text { tory/expert meeting }\end{array}$ \\
\hline 14 & $\begin{array}{l}\text { Nanotechnology in perspec- } \\
\text { tive - risk to man and the en- } \\
\text { vironment }\end{array}$ & 2008 & $\begin{array}{l}\text { National Institute for } \\
\text { Public Health and the } \\
\text { Environment (RIVM) }\end{array}$ & Risk analysis \\
\hline 15 & NanoNed & 2005-2010 & Researchers & $\begin{array}{l}\text { Technology } \\
\text { assessment }\end{array}$ \\
\hline 16 & $\begin{array}{l}\text { Nanopodium: Societal dialo- } \\
\text { gue on nanotechnology }\end{array}$ & 2009-2011 & CSDN & $\begin{array}{l}\text { Deliberative/ } \\
\text { Participatory }\end{array}$ \\
\hline
\end{tabular}

The case study results were validated by interviews with 12 central actors in nanotechnology assessment and governance, in particular related to the Dutch context. In addition a workshop was organised in the Netherlands where findings were presented and concepts of integration were discussed. In addition, empirical work literature studies were conducted, focusing on central contributions in the applied nano-ethics, technology assessments, and science and technology studies (STS) literature.

\section{Analysis of the integrated characteristics of assessments of nanotechnology in food and agriculture}

We will now present results from the case study in relation to the dimensions of integration presented in Table 2.

(a) Inclusion of all areas of topics into assessments: This dimension expresses a call for comprehensive assessments. Such integration does not necessarily involve formulas for comparing and balancing the diverse topics in a common currency ('strong' integration). The case study workshop made clear that this was a much too ambitious goal for nanofood. Inclusion of all areas of topics into assessments may, however, simply involve a consideration of the complexity of impacts that will need to be taken into account in respon- 
sible governance ('weak' integration). Such integrated assessments are found in the case study (such as the Nanopodium and the Science and Technology Options Assessment (STOA) reports).

(b) Inclusion of values into assessments: First, it should be noted that with regard to this interpretation, Scrase and Sheate (2002) specifically refer to environmental values. We, however, interpret it here as values in general. Sustainability assessments usually do not include specific deliberation on ethical issues of a more 'inherent' character, typically issues concerning 'playing God', respecting the integrity of human beings or animals, reverence for life, violating what is 'natural', and so on. However, such issues may exactly be a great concern for people related to emerging technologies. Integration on this dimension should therefore include a possibility for deliberating on a wide set of value issues in a systematic way that may actually impact assessment outcomes. In this study, ethical issues are, not surprisingly, mainly addressed in technology assessments, deliberative forums, and by non-governmental organisations (NGOs). Though one cannot expect a full-blown ethical review in assessments targeted to a particular topic such as human health risks, better integration along this dimension could be achieved if the assessments positioned themselves clearer in a broader value landscape. This implies clearly addressing what values have been guiding the work and what societal values the assessment does and does not address.

(c) Inclusion of narratives into assessments: Narratives are shared interpretative frameworks for understanding our social reality and incorporate the unknown into the register of the possible (Garcia-Lorenzo 2010: 330), often normatively laden (McCarthy 2003). Some interpret narratives as 'lay ethics' and this approach was taken in the European Deepen project (Deepening Ethical Engagement and Participation in Emerging Nanotechnologies) (Nordmann \& Macnaghten 2012; Dupuy 2010). Explicating narratives may be a matter of integration as it may serve to better identify sources of conflicts and thereby address these in a more comprehensive manner. While the Deepen project focused on the importance of narratives in understanding public attitudes and concerns about nanotechnologies, we would like to stress that narratives matter not only for the public. Conflicting and often implicit narratives about nature, science, and technology among different experts may create problems in conducting interdisciplinary dialogue in assessments and in communication between assessors and policy makers or stakeholders. In the case study we found that narratives and worldviews are hardly ever explicitly discussed in the assessments ${ }^{3}$ (even if this has been an approach in nano-ethics literature). It appears that if assessments are to have a mediating role (by reconciling opposing views), they should to a larger extent address both underlying narratives and values.

(d) Not isolating one topic at the expense of the whole: This dimension captures the concern with fragmentation and lack of reflectivity on the larger picture. In the case of nanotechnology in food, packaging, and agriculture, one might claim that the problem is rather that the assessments are too broad, not too narrow. Most assessments concern nanotechnologies in general, which is an extremely broad field. Though this has perhaps been necessary in the early stages of technology development, this broadness has the implication that the richness of each particular topic (such as nano-sensors in crop mana- 
gement) is not addressed, and the whole picture of this particular topic is not addressed. The time is now ripe for more topic-specific assessments.

(e) Explicating assessment framing: How assessments are framed will ultimately determine on their outcomes. (Stirling 2008) mentions the following important framing questions in relation to technology assessments:

Choosing policy questions, bounding institutional remits, prioritizing research, including disciplines, accrediting expertise, recruiting committees, setting agendas, structuring inquiry, forming hypotheses, choosing between methodologies, defining metrics, characterizing decision options, prioritizing criteria, interpreting uncertainties, setting baselines, exploring sensitivities, conducting peer review, and constituting proof. (Stirling 2008: 275)

In this interpretation, integrated assessment is an assessment that reflectively positions itself in a context of alternative framing options, showing an integrated perspective on its own assumptions. Stirling's own observation is that ' $[t]$ hese factors are generally considered external to analysis and are excluded from explicit reflection. Many are essentially subjective in nature and are thus eminently contestable. Yet, they often exert a determining influence on appraisal results, the full scope of which typically remains concealed or underacknowledged' (Stirling 2008: 275).

It is hard to assess the adequacy of the assessments' reflection on framing issues. Overall, the assessments in the nano-food case study score high on transparency. They generally include lists of involved experts, reference lists, and so on revealing important assumptions in their work. More transparency could be called for in all the assessments: transparency about the choice of literature, about decisions on the relevance of various possible assessment topics, about interpretations of concepts and research results, and so on. However, assessment reports can never include absolutely all information if they are to be readable. That a framing issue is not reported does not imply that it has not been addressed. There is no standard for what is appropriate transparency and reflection on framing issues, and we will here simply note that increased integration on this dimension is overall possible. Such increased reflection should be carried out in dialogue with interested parties that are able to challenge such frames.

(f) Some specific elements (like anticipation) are necessary in assessments: Integration might involve specific methodological elements. Anticipation is perhaps the most immediately crucial element in the context of emerging science and technologies as the technologies' impacts may be uncertain and often only manifested in the longer term. The currently important concept in European research policy, Responsible Research and Innovation (RRI) (see Schomberg 2012), which is in itself an integrated approach that involves technology assessment, stresses the importance of anticipation. Most assessments in the case study may be said to be already integrated in the sense that they include anticipation. However, even if there is a future approach in the assessments, there is not much systematic reflection on future technology and governance options and challenges.

Another element that could be argued to be central in assessments of emerging science and technologies is deliberation on alternative technology paths, in order to avoid an unnecessary technology focus or path dependencies. For instance, with regard to 
nano-sensors used in crop monitoring, perhaps it would be better to assess the variety of alternatives to better crop management, rather than assessing the particulars of nanosensors.

(g) Targeted use of methods in assessment: Several of our informants in the project have stressed that there is no need for an all-encompassing assessment. What is needed are rather well-targeted assessments, assessments that are designed to fit the specific situation, determined in a comprehensive situation analysis of the dynamic technology and governance picture. This might mean that there is sometimes a need for broad participatory assessments, while in other circumstances a well-designed expert group focusing on a limited topic might give the most relevant input for coherent and responsible policy making. Practitioners from the TA domain (Decker \& Ladikas 2004) have stressed the need for explicit and reflective methodology choice. In the context of integrated assessment, this means systematic assessment design based on an integrated analysis of the topic. This design also involves clearly identified relations between assessment elements (e.g. expert group deliberations and a stakeholder consultation event or a public opinion survey), in order to clarify the different elements' contribution to the outcome of the assessments.

From the case study we see that in general there is not much reflection on methods in the analysed assessments in the sense that there is not much information on the reasons for their particular choice of methods in the context of other possible assessment designs. The assessments could be better integrated - in this meaning of the term integrated - by being more explicit on their design choices, for instance by referring to systematic methodological frameworks.

(h) Integration of stakeholders/the public into assessments: Scrase and Sheate (2002) speak about integration of stakeholders into governance, but we would here like to include as a separate dimension the integration of stakeholders and the public into assessment. Strand (2011), for instance, argues that judging the quality of new products in the broadest sense - technical, ethical, and political - should be a collective societal task. From the case study, it appears as though public participation is not considered so important in European nanotechnology governance anymore, though the Organization for Economic Cooperation and Development (OECD) Working Group on Manufactured Nanomaterials is currently developing guidelines for public deliberation processes. This probably reflects the fact that nanotechnology has so far not evoked so much public interest after all, and that there is in many circles a consensus that what is now needed is good risk assessment methodology. Such assessments are therefore more expert-based.

With regard to integrating stakeholders into assessment we should note that Scrase and Sheate (2002) argue that integrating business representatives into governance does not necessarily lead to more sustainable policies. Equal stakeholder participation seems to be a fair principle, but if market actors already are influencing the technology development significantly, such 'equal' participation may simply reinforce existing power structures. When all stakeholders are allowed to participate, this may easily leave much room for influence by industrial interests, which usually have more resources to fund participation than consumer and societal organisations (CSOs) have. When integrating stakehol- 
ders it is therefore important that CSOs, and not only industrial interests, are included. However, we have seen that in the Netherlands relevant NGOs are no longer prioritising nanotechnology. There is therefore a risk that stakeholder involvement will lead to increased industrial influence on policies.

(i) Integration among assessments: Integration among assessments involves seeing assessments in their context of other assessments, and identifying division of work, fields of overlap, and, possibly, potentials for cooperation between assessment institutions. In the case study we found that there is a number of thematically more or less overlapping assessments. While some refer to earlier assessments in other assessment domains (the STOA report refers to the report by Friends of the Earth, to risk assessments, etc.), others appear to operate independently (this holds in particular for more specialised assessments). Van Est et al. (2012: 14) show that there are weak connections between different societal spheres (the political, the science and technology sector, and the public) in Dutch nanotechnology assessment. If better integration of assessments across societal spheres are called for, this seems to require systematic learning processes in order to overcome disciplinary and organisational boundaries.

(j) Integration of governance concerns into assessments: Integration might mean designing assessments in order to contribute to responsible research and innovation (RRI) or other governance goals. This implies closer dialogue between risk assessors and risk managers, or between assessors and recipients/commissioners in general, in order to ensure that relevant policy topics are being addressed. It may also involve systematic consideration of trends likely to impact on policy making and governance options. Among the most relevant trends are liberalisation, internationalisation, the recognition or negligence of sustainability concerns, and changing expectations of democratisation. The impression from the case study was that such trends, although in many cases discussed, were seldom systematically considered (the International Risk Governance Council (IRGC) report being the most notable exception).

(k) Better integration of assessments into governance: The assessments' integration into governance will depend on the status of the assessment organisation, the focus of the assessment, and so on. It is notoriously difficult to pinpoint how deliberative processes impact on policy making (Decker \& Ladikas 2004), and this was hard also in our case study. However, (Kaiser et al. 2010) stress that public deliberation processes may still have indirect effects on public opinion and decision makers, for instance by setting agendas, and learning may take place without anyone being able to document it. The participatory processes of the start of the period generated much information about governance needs. Though policy impact might not have been the purpose of these assessments in the first place, they do provide information that would seem of relevance for policy makers. It is important that this information is used in governments' subsequent risk and impact assessments. Moreover, results from risk and impact assessments again need to inform deliberative platforms. 


\section{Discussion}

We have analysed the findings from the EST-Frame case study on a number of interpretations or dimensions of integration. A number of objections against integrated assessments can be voiced, but these will apply only to specific interpretations of integration. As noted earlier, Scrase and Sheate (2002) point out that calling for integrated assessments will not necessarily lead to more sustainable or responsible developments. For instance, integration as including business concerns, or industry as a stakeholder, into assessments may reinforce existing power relations. In their opinion, this might well reinforce the power of economic interests that have already been a prominent cause of environmental and social harms. However, we will claim that this only holds for unbalanced stakeholder involvement. With empowered CSOs such integration might be a vehicle for responsible technology governance. Scrase and Sheate also point to other challenges of integrated assessment models such as oversimplification or a loss of transparency (Scrase \& Sheate 2002: 289). This would be applicable mostly to point (a) mentioned earlier.

Another objection is to point out the risk of integrated assessments taking the place of political decision making. In this perspective, making integrated decisions is the core of politics, and the call for an integrated assessment might in effect be a call for moving such integration out of institutionalised politics into a technocracy-driven domain without democratic legitimacy. This topic is part of a larger discussion of the relation between experts and policy makers, the commission and use of advice by policy makers and politicians, and the democratic legitimacy of public engagement activities. It is outside the scope of this article to address these discussions in detail; we will simply here note that this topic needs to be addressed in the dialogue between assessors and policy makers in the discussion of assessment gaps and integration needs in given technological fields.

After presenting their objections to integrated assessment approaches, Scrase and Sheate claim that a better strategy would be to seek to understand 'path dependencies' determining decisions, and focus on the processes of learning that contribute to political and institutional change (Scrase \& Sheate 2002: 289). However, in our opinion, this is not an alternative to integrated assessment, but rather a condition for engaging in integrated assessment in the meanings of points (a) to (e). Therefore, integrated assessments, if designed and implemented in the right way, may be useful instruments for responsible governance of emerging technologies. However, comparing the four case studies in the EST-Frame project (nano-food, synthetic biology, biofuels, and cloud computing), we see that there is no 'one size fits all' approach. There are different integration needs depending on the situation; the maturity of the technology, the level of social awareness and controversy regarding the technology, and so on. In our view, the common concern for responsible governance of emerging science and technologies related to integrated assessment is a need for systematic reflection on the relevant assessment landscape in order to identify integration needs - in line with what we have been doing here. In our experience such reflection is rare. Of course, this is not necessarily an easy task; in fact, we met several challenges in the EST-Frame case studies, including the one presented here. When we now turn to a discussion of the approach and findings in the case study, this will therefore 
at the same time shed light on challenges of assessing integration needs in an assessment field in general.

First, there is the issue of scope. What counts as an assessment of nano-food? Should assessments on emerging food technologies in general be included, even if they only contain a couple of pages on nanotechnology? Second, there is the definition of assessments versus ordinary research articles. Where should the line be drawn? Third, from the potentially numerous studies, which should be reviewed in detail? In the EST-Frame these choices were made in the consortium, with our research purposes in mind. In the reviews of the assessment 'landscape' and of integration needs that we here recommend for responsible governance, these choices should be made in broad dialogue, in order to ensure stakeholder and public legitimacy (Forsberg 2012).

Second, any selection and review of assessments have an irreducible subjective aspect, in spite of carefully developed research protocols. In order to ensure an aligned practice across the assessors and case studies in the EST-Frame, a 'calibration group' was established to discuss potential differences in understanding. However, in spite of the calibration it should be clear that the reviews of the assessments are based on the assessor's judgements. Moreover, the selection of the assessments, though carefully made, will still necessarily impact on the general reflections presented in this article. Because of these potential biases we have been careful to validate our findings with representatives from the field, and we also interpret our findings on the basis of published literature in the field of technology assessment and governance. We believe that with this triangulation our reflections, conclusions, and recommendations are likely to be relevant and informative, even if they would not hold for any selection of assessments in the field.

Third, it should be noted that these analyses are not complete. Other examples could have been discussed under each interpretation and comprehensive analyses of integration could have been carried out for each individual assessment. However, the purpose here was to present some impressions of integration challenges in the field of nano-food assessments in general, and the level of detail and comprehensiveness was adapted to this purpose. More detail can be found in the EST-Frame deliverable 2.1, published on the project website (www.estframe.net).

Finally, the usefulness of the current categorisations of integrated assessments may be debated. Several of the dimensions are partly overlapping and there are many relations between these dimensions. These categorisations must be seen as tentative and their usefulness for analysing integration of assessments will be further tested in the EST-Frame project. They must therefore be regarded as tentative and up for discussion. However, our preliminary experience is that they are useful for reflecting on a wide spectrum of integration concerns.

\section{Conclusion}

In this article we have outlined the complexities of integrated assessment and analysed the status of assessments of nanotechnology in food and agriculture based on the different 
interpretations of integrated assessment given in Table 2. We have found that though individual assessments may be well integrated on a number of these dimensions, there is in general room for better integration with regard to most of the identified dimensions. More specifically, assessments should be more reflected on their point of departure with regard to values, narratives, and the framing of their topic. There is a need for more specific assessments, addressing topics in their complex particularities rather than only generic assessments. These should also take more systematically into account trends affecting technology and the possibility for technology governance. Finally, more attention should be paid to learning processes between assessments, and between assessments and policy makers. True interdisciplinarity and even trans-disciplinarity amounts to one of the most important challenges in the assessment of an emerging technology field such as nanotechnology in food and agriculture. Such interdisciplinary dialogue should include a discussion on what dimensions of integration seem to be needed for responsible governance in this field. Our contribution here has simply been to point out such dimensions. However, this discussion is still at an early stage and we call for additional contributions to this debate.

\section{Acknowledgements}

The first part of this article is built on the paper 'Integrated assessments of emerging food technologies - some options and challenges' (Forsberg 2012b). The work in the rest of the article is carried out as a part of the European project Integrated EST Framework, a 7th Framework Programme, Science-in-Society (see www.estframe.net). The authors would like to thank the journal editors and two anonymous reviewers for their important advice, much improving the article. We would also like to thank Kamilla Kjølberg, who contributed with some reviews in the case study and with input to an earlier version of the article. Finally, we thank the whole EST-Frame consortium for important discussions on integration of assessments.

\section{Notes}

${ }^{1}$ There is a current trend in research on ethical, legal, and social aspects of new technologies (the socalled ELSA research) to design integrated projects where, typically, social scientists or philosophers take part in natural science projects, often even being part of laboratory work. Though integrated research projects are not central to the EST-Frame approach, the so-called constructive technology assessment (Schot \& Rip 1996) and midstream modulation (Fisher, Mahajan \& Mitcham 2006) are important directions in current research.

${ }^{2}$ For more on the method and detailed results please see the case study report published on www.estframe.net.

${ }^{3}$ The exception is that two TA reports and two deliberative projects discussed visions. 


\section{References}

Chen, H. \& Yada, R. (2011) Nanotechnoogies in agriculture: New tools for sustainable development. Trends in Food Science \& Technology, 22, pp. 585-594.

Council of the European Union (2006) Renewed EU sustainable development strategy. Brussels: Council of the European Union.

Decker, M. \& Ladikas, M. (eds.) (2004) Bridges between science, society and policy. Technology assessment - methods and impacts. Berlin, Heidelberg \& New York: Springer.

Dupuy, J.-P. (2010) The narratology of lay ethics. Nanoethics, 4, pp. 153-170.

European Commision (2008) Commission recommendation on a code of conduct for responsible nanosciences and nanotechnologies research. Brussels: European Commision.

European Commision (2009a) Mainstreaming sustainable development into EU policies: 2009 Review of the European Union strategy for sustainable development. Brussels: European Commision.

European Commision (2009b) Impact assessment. Brussels: European Commision. Retrieved $20^{\text {th }}$ November 2011 from: http://ec.europa.eu/governance/better_regulation/ impact_en.htm\#_approach

European Commision (2010) Work programme 2011, Capacities, part 5, Science and Society. Brussels: European Commision.

Fisher, E., Mahajan, R. L. \& Mitcham, C. (2006) Midstream modulation of technology: Governance from within. Bulletin of Science, Technology \& Society, 26, pp. 485-496.

Forsberg, E.-M. (2012a) Standardisation in the field of nanotechnology: Some issues of legitimacy. Science and Engineering Ethics, 18, pp. 719-739.

Forsberg, E.-M. (2012b) Integrated assessments of emerging food technologies - some options and challenges. In Climate change and sustainable development. Ethical perspectives on land use and food production, eds. T. Potthast \& S. Meisch, pp. 275-279. Wageningen: Wageningen Academic Publishers.

Garcia-Lorenzo, L. (2010) Framing uncertainty: Narratives, change and digital technologies. Social Science Information, 49, pp. 329-350.

Gaskell, G., Stares, S., Allandsdottir, A., Allum, N., Castro, P., Esmer, Y. et al. (2010) Europeans and biotechnology. Brussels: European Commission.

Kaiser, M., Kurath, M., Maassen, S. \& Rehman-Sutter, C. (eds.) (2010) Governing future technologies. Nanotechnology and the rise of an assessment regime. Dordrecht/Heidelberg/London/New York: Springer.

McCarthy, J. (2003) Principlism or narrative ethics: Must we choose between them? Journal of Medical Ethics, 29, pp. 65-71.

Nordmann, A. \& Macnaghten, P. (2012) Engaging narratives and the limits of lay ethics: Introduction. Nanoethics, 4, pp. 133-140.

Schomberg, R. V. (2012) Prospects for technology assessment in a framework of responsible research and innovation. In Technikfolgen abschätzen lehren: Bildungspotenziale transdisziplinärer Methoden, eds. M. Dusseldorp\&R. Beecroft, pp. 39-62. Wiesbaden: Vs Verlag.

Schot, J. \& Rip, A. (1996) The past and future of constructive technology assessment. Technological Forecasting \& Social Change, 54, pp. 251-268.

Scrase, J. I. \& Sheate, W. R. (2002) Integration and integrated approaches to assessment: What do they mean for the environment? Journal of Environmental Policy \& Planning, 4, pp. 275-294.

Sozer, N. \& Kokini, J. L. (2009) Nanotechnology and its applications in the food sector. Trends in biotechnology, 27, pp. 82-89.

Stirling, A. (2008) 'Opening up' and 'closing down'. Power, participation, and pluralism in the social appraisal of technology. Science, Technology \& Human Values, 33, pp. 262-294. 
Strand, R. (2011) Nano-ethics. In Nanotechnology in the agri-food sector - implications for the future, eds. L. J. Frewer, W. Norde, A. Fischer \& F. Kampers, pp. 271-281. Weinheim: Wiley$\mathrm{VCH}$ Verlag GmbH \& Co.

United Nations General Assembly (2005) 2005 World Summit Outcome. New York: UNGA. 